\title{
APPLICATION OF THE KRIGING METHOD TO DRAW ISOSEISMAL MAPS OF THE SIGNIFICANT 2002-2003 COSTA RICAN EARTHQUAKES
}

\author{
Lepolt Linkimer ${ }^{1,2^{*}}$ \\ ${ }^{1}$ Universidad de Costa Rica, Instituto de Investigaciones en Ingeniería, Laboratorio \\ de Ingeniería Sísmica, Apdo. 36-2060, San Pedro Montes de Oca, Costa Rica. \\ ${ }^{2}$ Universidad de Costa Rica, Escuela Centroamericana de Geología, Sección de \\ Sismología, Vulcanología y Exploración Geofísica, Apdo. 214-2060, San Pedro de \\ Montes de Oca, Costa Rica. \\ *Present address: The University of Arizona, Department of Geosciences, Gould- \\ Simpson 208, Tucson AZ, 85721. USA. \\ linkimer@email.arizona.edu.
}

(Recibido 08/09/2007; aceptado 19/12/2007)

\begin{abstract}
The Kriging method is documented for the first time to draw isoseismal maps of Costa Rican earthquakes. This method is recommended to replace the visual interpolation technique that has traditionally been used in Costa Rica. Kriging is demonstrated using macroseismic data from four significant events: the January 28, 2002 Bijagua de Upala (5.4 Mw); the July 31, 2002 Burica (6.2 Mw); the September 16, 2003 Puriscal (5.4 Mw), and the 2003 Christmas (6.6 Mw) earthquakes. Isoseismals that best fit the observed intensity data field are calculated by modeling a simple linear variogram. Earthquake effects and Peak Ground Acceleration (PGA) recorded by the Laboratory of Earthquake Engineering (LIS) are also documented for these earthquakes. The Puriscal and Bijagua earthquakes produced minor damage in the epicentral areas, where the Modified Mercalli Intensity (MMI) observed was V and VI, respectively. The Burica and Christmas earthquakes produced moderate damage in localities of the Panama-Costa Rican border region, where the MMI was VII and VIII, respectively.

Keywords: Isoseismal maps, Kriging method, Modified Mercalli Intensity, peak ground acceleration, earthquake effects.
\end{abstract}

RESUMEN: El método de Kriging es documentado por primera vez en Costa Rica para dibujar mapas de isosistas. Esta técnica es recomendaba para reemplazar la interpolación visual que tradicionalmente ha sido usada en Costa Rica. Kriging es demostrado usando información macrosísmica de cuatro sismos importantes: Bijagua de Upala del 28 de enero del 2002 (5,4 Mw), Burica del 31 de julio del 2002 (6,2 Mw), Puriscal del 16 de septiembre del 2003 (5,4 Mw) 
y Navidad del 2003 (6,6 Mw). Las isosistas que mejor representan el campo de datos de intensidades observado fueron calculadas modelando un simple variograma lineal. También son documentados los efectos de estos sismos y el valor máximo de la aceleración del terreno (PGA) registrado por las estaciones del Laboratorio de Ingeniería Sísmica (LIS). Los sismos de Puriscal y Bijagua produjeron daños menores en la zona epicentral, en donde la intensidad Mercalli Modificada (MMI) observada fue de V y VI respectivamente. Los sismos de Burica y Navidad produjeron daños moderados en las localidades de la zona fronteriza entre Panamá y Costa Rica, donde el MMI observado fue de VII y VIII respectivamente.

Palabras clave: Mapas de isosistas, método de Kriging, intensidad Mercalli Modificada, aceleración pico del suelo, efectos de los sismos.

\section{INTRODUCTION}

Isoseismal maps show the spatial distribution of seismic intensities reported for a specific earthquake throughout a region. Seismic intensity is a parameter that describes the degree of ground shaking for an earthquake. It is based on human response to ground shaking and earthquake effects and is commonly measured using the Modified Mercalli Intensity (MMI) scale, expressed using Roman numerals between I and XII (Wood \& Newman, 1931; Richter, 1958). Isoseismals are lines that bound regions of common ground shaking and their shape depends on many factors, such as local geology, topography, crustal attenuation structure, and earthquake radiation pattern, size, and focal depth. The instrumentally-recorded equivalent of the seismic intensity is ground acceleration, commonly expressed in $\mathrm{cm} / \mathrm{s}^{2}$ (= 1 gal).

Isoseismal maps allow for the direct visualization of earthquake effects. Isoseismals drawn within a few minutes of the earthquake occurrence are particularly valuable for emergency response purposes. Empirical relationships that involve isoseismals can be used to determine epicentral location, focal depth, magnitude, and seismogenic zone geometry (e. g., Shebalin, 1973; Nuttli \& Zollweg, 1974; Gupta \& Combs, 1978; Rojas et al., 1993; Frankel, 1994; Albarello et al., 1995; Gasperini et al., 1999) and to discriminate between upper-crustal and subduction earthquakes (White \& Harlow, 1998). These empirical relationships are particularly relevant to historical earthquakes, for which no instrumental recordings exist. Isoseismal maps are also applied to seismic hazard assessments and attenuation relationships (Papazachos, 1992).
In Costa Rica, isoseismal lines have traditionally been drawn based on the visual interpolation of MMI data by local experts. Local geology has been taken into account as criteria when isoseismal lines are drawn for certain isoseismal maps (W. Montero, pers. com., 2007). The isoseismal line interpreter faces the problem that the MMI data field is usually restricted to a $120-220 \mathrm{~km}$ wideland isthmus, which in most cases does not permit the interpreter to close isoseismal lines, determine their shapes, or observe trends that facilitate the trace line drawing. Isoseismal maps from some historical and recent Costa Rican earthquakes have been published by Montero \& Miyamura (1981), Boschini \& Montero (1994); Barquero \& Rojas (1994), Peraldo \& Montero (1994; 1999), Mora \& Yasuda (1994), Suárez et al. (1995), White \& Harlow (1998), Montero (1999), and Rojas \& Redondo (2002), among others.

Although the available isoseismal maps have been carefully drawn by the interpreters, the process of drawing isoseismal lines is not standardized and the criteria used may be different from one interpreter to another. This issue was identified by De Rubeis et al. (1992), who showed the contrasting isoseismal traces drawn by three different authors using essentially the same intensity data set for the 1683 Sicilian earthquake. The uncertainties in the way seismologists interpret macroseismic data and the problem of drawing objective isoseismal maps has also been discussed by Davidson (1921), Cecić et al. (1996), De Rubeis et al. (2005), and Schenková et al. (2007).

The main goal of this study is to introduce in Costa Rica the use of an objective, homogeneous, and automatic isoseismal map drawing method using kriging interpolation, a method previously applied to seismic intensity data in Italy 
(Gasparini et al., 2003; DeRubeis et al., 2005) and Greece (Schenková et al., 2007).

Intensity maps drawn using the kriging method are presented for four significant seismic events: the January 28, 2002 Bijagua de Upala (5.4 Mw); the July 31, 2002 Burica (6.2 Mw); the September 16, 2003 Puriscal (5.4 Mw), and the 2003 Christmas (6.6 Mw) earthquakes. This paper also documents Peak Ground Acceleration (PGA) values and summarizes damage and effects observed in the regions that experienced the highest intensities.

The utilization of a norm in which identical conditions are used for drawing each particular isoseismal map, would allow for the creation of standardized maps that would be less susceptible to subjective line interpretation. Another application is that isoseismal maps could be generated faster and automatically. Intensity maps could also be rapidly generated using MMI data obtained from PGA values based on available MMI vs. PGA empirical relationships for Costa Rica (Linkimer, 2007: this number). This would offer the possibility of creating fast intensity maps like those produced in the United States, within a few minutes after an earthquake occurs (Wald et al., 1999).

\section{Seismic sources and seismicity in Costa Rica}

Costa Rica is located in a seismically active region where the interaction of the Cocos, Caribbean, and Nazca plates as well as the Panama microplate occurs (Fig. 1). The National Seismological Network of Costa Rica (RSN), which comprises the earthquake unit of the Central American School of Geology of the University of Costa Rica (UCR) and the Costa Rican Institute of Electricity (ICE), records between 2000 and 6000 earthquakes every year. The average number of earthquakes felt annually in the country between 1992 and 2006, was 128 . The majority of these earthquakes are associated with the subduction of the Cocos plate beneath the Caribbean plate, the North Panama Deformed Belt (NPDB), the Panama Fracture Zone (PFZ), as well as crustal faults located in the interior of the country.

\section{METHODOLOGY}

Earthquake location and magnitude were acquired from the RSN (Table 1). PGA came from the Laboratory of Earthquake Engineering (LIS) at UCR (Table 2). The LIS and RSN have permanent networks of seismographs and accelerographs, respectively, distributed throughout Costa Rica. The location of accelerographs that recorded the studied events is shown in figure 1 . These instruments are all digital, models Etna, K2, SSA1, SSA-2, and SMA-QDR from Kinemetrics, Inc. The soil type at the strong motion stations was classified into four types according to the latest version of the seismic code of Costa Rica (Colegio Federado de Ingenieros y Arquitectos, 2003): Rock, Hard, Soft, and Very Soft (Table 2).

MMI values were assigned based on interviews made at different localities throughout Costa Rica, Panama, and Nicaragua during the week of the earthquake occurrence. Interviews were made either by phone or at the localities using a questionnaire based on Richter (1958). An average value of MMI was assigned to the whole town where the interviews were performed. For each earthquake, an MMI data field was built and isoseismal lines were determined using the kriging interpolation method of the Surfer Program Package (Surface Mapping System, product of Golden Surfer, Inc) version 8.05 for Windows.

\section{The Kriging interpolation method}

Kriging is a statistical technique that estimates unknown values at specific points in space using data values from known locations. The method was first developed as an attempt to accurately predict ore reserves in mines of South Africa (Krige, 1951; Matheron, 1963). Kriging was later recognized as a good spatial interpolator in many other fields within Geosciences, particularly in Hydrogeology, Geochemistry, Remote Sensing, Seismology and Environmental Sciences (Cressie, 1990).

The main assumption when using kriging is that the data analyzed are samples of a regionalized variable, as is assumed to be the case with intensity 


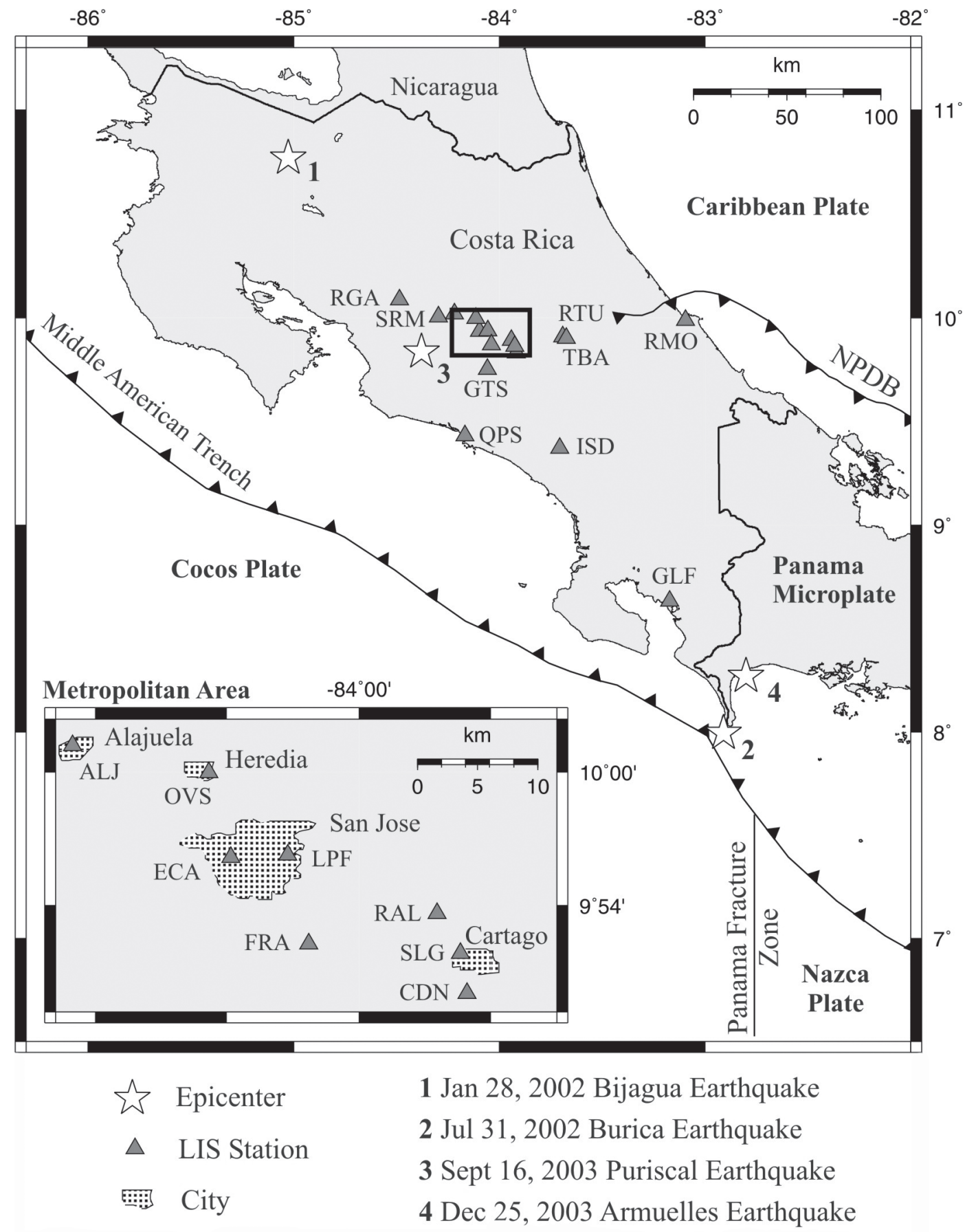

Fig. 1: Major tectonic features of Costa Rica and epicentral location of the studied earthquakes. LIS ground motion stations that recorded the studied events are also shown. NPDB: North Panama Deformed Belt. 
Table 1

Characteristics of the studied earthquakes according to RSN

\begin{tabular}{|c|c|c|c|c|c|c|c|}
\hline Day-month-year & UTC Time & Lat. & Long. & Depth $(\mathrm{km})$ & Mw & Epicentral location & Highest MMI \\
\hline $28-01-02$ & $02: 49$ & 10.769 & -85.026 & 4.0 & 5.4 & $\begin{array}{c}5 \mathrm{~km} \text { NE of Bijagua } \\
\text { de Upala }\end{array}$ & $\begin{array}{l}\text { VI Bijagua and El } \\
\text { Pilón de Upala }\end{array}$ \\
\hline $31-07-02$ & $00: 16$ & 7.995 & -82.909 & 10.0 & 6.2 & $\begin{array}{c}10 \mathrm{~km} \mathrm{~S} \text { of Punta } \\
\text { Burica }\end{array}$ & $\begin{array}{l}\text { VII Puerto } \\
\text { Armuelles }\end{array}$ \\
\hline $16-09-03$ & $20: 03$ & 9.837 & -84.378 & 54.9 & 5.4 & $\begin{array}{c}7 \mathrm{~km} \text { SW of Santiago } \\
\text { de Puriscal }\end{array}$ & $\begin{array}{c}\text { V Pavas, } \\
\text { San Ramón, } \\
\text { Guadalupe }\end{array}$ \\
\hline $25-12-03$ & 07:11 & 8.271 & -82.800 & 26.0 & 6.6 & $\begin{array}{c}7 \mathrm{~km} \text { E of Puerto } \\
\text { Armuelles }\end{array}$ & $\begin{array}{l}\text { VIII Finca } \\
\text { Naranjo }\end{array}$ \\
\hline
\end{tabular}

data. A regionalized variable varies continuously in such a manner that points near each other, have a certain degree of spatial correlation, but points that are widely separated are statistically independent. A kriging estimator is said to be linear because the predicted value $\left(\mathrm{G}_{\mathrm{j}}\right)$ at any grid node is a linear combination that may be written as:

$$
\text { (1) } G_{j}=\sum_{i=1}^{n} w_{i j} Z_{i}
$$

Where $\mathrm{n}$ is the number of points used to interpolate at each node, $\mathrm{Z}_{\mathrm{i}}$ is the $\mathrm{Z}$ value (MMI in this case) at the $\mathrm{i}^{\text {th }}$ point, and $\mathrm{w}_{\mathrm{ij}}$ is the weight associated with the $\mathrm{i}^{\text {th }}$ data value when computing $\mathrm{G}_{\mathrm{j}}$. The weights are solutions of a system of linear equations which are obtained by assuming that $\mathrm{G}$ is a sample-path of a random process and that the error of prediction is minimal.

The Kriging algorithm assigns weights to each point based on the distance between the point to be interpolated and the data location $(h)$, as well as the inter-data spacing. Other parameters, such as length scale, repeatability, and direction dependence of data are also considered for assigning weights. These parameters are entered into the algorithm via the variogram $\gamma(h)$, which is an analytical tool that quantifies the degree of spatial autocorrelation of data. For intensity data, a twodimensional variogram can be modeled using a power law relation (De Rubeis et al., 2005):
(2) $\gamma(\theta, h)=C_{0}+S h^{*}$

The length scale is given by the variogram range (or slope, $\mathrm{S}$ ) and the data repeatability is specified by the nugget effect $\left(\mathrm{C}_{0}\right)$. The direction $(\theta)$ dependence, given by the anisotropy (A), can be added to the model using a three-dimensional variogram $\gamma(\theta, \mathrm{h})$. A detailed explanation of the Kriging algorithm and the variogram parameters can be found in Matheron (1963), Davis (1973), Isaaks \& Srivastava (1989), Cressie (1990; 1991), and De Rubeis et al. (2005).

The isoseismals that more accurately represented the observed intensity data field were chosen by modeling a simple linear variogram based on the kriging options of the Surfer Package. Some of these options were used by Schenková et al. (2007) for drawing isoseismal maps in Greece. These options were:

1. Point Kriging. This option estimates the values of points at the grid nodes, as opposed to the block kriging option, which estimates the average value of rectangular blocks centered on the grid nodes.

2. Drift type: none. This refers to the Ordinary Kriging method in which spatial data are assumed to be stationary, that is, the mean and variance of the scatter point data set are constant over time and position.

3. Linear variogram model with a slope of $\mathrm{S}=1$. This is the same as a power variogram with 
Table 2

Peak ground acceleration $(\mathrm{cm} / \mathrm{s} 2)$ recorded at LIS stations

\begin{tabular}{|c|c|c|c|c|c|c|c|}
\hline Day-Month-Year & Station & Dist. $(\mathrm{km})$ & $\mathrm{Z}$ comp. & N-S comp. & E-W comp. & $\begin{array}{l}\text { Soil type at } \\
\text { station }\end{array}$ & $\begin{array}{c}\text { Type of accelero- } \\
\text { graph }\end{array}$ \\
\hline 2002-07-31 & GLF & 77 & 15.5 & 23.5 & 32.6 & Rock & ETNA \\
\hline $2002-07-31$ & ISD & 177 & 5.9 & 11.0 & 11.4 & Soft & SSA-2 \\
\hline 2002-07-31 & QSP & 211 & 8.9 & 18.0 & 18.0 & Rock & ETNA \\
\hline $2002-07-31$ & RMO & 223 & 6.5 & 12.9 & 13.7 & Very soft & ETNA \\
\hline $2002-07-31$ & $\mathrm{CDN}$ & 233 & 3.1 & 5.0 & 5.5 & Hard & SSA-1 \\
\hline $2002-07-31$ & FRA & 233 & 2.1 & 5.7 & 4.3 & Hard & SMA-QDR \\
\hline $2002-07-31$ & SLG & 236 & 4.4 & 12.6 & 13.8 & Soft & ETNA \\
\hline $2002-07-31$ & RAL & 240 & 5.5 & 13.1 & 11.0 & Hard & ETNA \\
\hline $2002-07-31$ & ALJ & 267 & 7.5 & 26.3 & 18.4 & Soft & ETNA \\
\hline 2003-09-16 & RGA & 59 & 6.6 & 15.9 & 13.4 & Soft & SSA-2 \\
\hline 2003-09-16 & ALJ & 61 & 10.1 & 16.4 & 23.7 & Soft & ETNA \\
\hline $2003-09-16$ & ECA & 64 & 13.5 & 34.1 & 39.9 & Soft & SSA-2 \\
\hline $2003-09-16$ & OVs & 65 & 2.7 & 3.6 & 2.4 & Soft & SSA-1 \\
\hline $2003-09-16$ & FRA & 66 & 7.5 & 8.9 & 10.1 & Hard & SMA-QDR \\
\hline $2003-09-16$ & LPF & 66 & 8.2 & 16.7 & 17.7 & Soft & $\mathrm{K} 2$ \\
\hline $2003-09-16$ & RAL & 73 & 9.5 & 11.0 & 15.3 & Hard & ETNA \\
\hline $2003-09-16$ & SLG & 74 & 6.2 & 35.7 & 22.1 & Soft & ETNA \\
\hline 2003-09-16 & $\mathrm{CDN}$ & 75 & 6.2 & 8.2 & 10.2 & Hard & SSA-1 \\
\hline $2003-09-16$ & QSP & 75 & 10.8 & 18.9 & 20.9 & Rock & ETNA \\
\hline $2003-09-16$ & ISD & 105 & 4.0 & 13.9 & 14.0 & Soft & SSA-2 \\
\hline $2003-12-25$ & GLF & 63 & 72.5 & 114.0 & 105.0 & Rock & ETNA \\
\hline $2003-12-25$ & ISD & 160 & 12.1 & 20.7 & 24.2 & Soft & SSA-2 \\
\hline $2003-12-25$ & RMO & 195 & 6.2 & 13.6 & 11.9 & Very soft & ETNA \\
\hline $2003-12-25$ & QSP & 199 & 13.9 & 27.7 & 41.3 & Rock & ETNA \\
\hline $2003-12-25$ & TBA & 207 & 8.6 & 19.4 & 28.6 & Soft & SMA-QDR \\
\hline $2003-12-25$ & RTU & 208 & 3.4 & 6.5 & 8.6 & Soft & SSA-2 \\
\hline $2003-12-25$ & $\mathrm{CDN}$ & 214 & 4.2 & 10.1 & 11.2 & Hard & SSA-1 \\
\hline $2003-12-25$ & FRA & 217 & 3.6 & 8.5 & 8.6 & Hard & SMA-QDR \\
\hline $2003-12-25$ & SLG & 217 & 7.8 & 32.1 & 33.2 & Soft & ETNA \\
\hline $2003-12-25$ & RAL & 221 & 7.2 & 17.1 & 19.3 & Hard & ETNA \\
\hline $2003-12-25$ & GTS & 225 & 6.8 & 15.2 & 22.2 & Soft & SMA-QDR \\
\hline $2003-12-25$ & LPF & 232 & 9.9 & 23.3 & 36.1 & Soft & $\mathrm{K} 2$ \\
\hline $2003-12-25$ & ECA & 235 & 11.3 & 31.7 & 33.0 & Soft & SSA-2 \\
\hline $2003-12-25$ & OVs & 242 & 4.1 & 6.1 & 6.0 & Soft & SSA-1 \\
\hline $2003-12-25$ & ALJ & 250 & 16.4 & 38.8 & 32.8 & Soft & ETNA \\
\hline
\end{tabular}




\begin{tabular}{llllcllc}
\hline $2003-12-25$ & RGA & 255 & 4.4 & 9.7 & 12.2 & Soft & SSA-2 \\
$2003-12-25$ & SRM & 275 & 13.4 & 16.7 & 20.3 & Soft & SMA-QDR \\
\hline
\end{tabular}

Notes: Dist.: Hypocentral distance; comp.: component.

$\alpha=1$. This parameter is used to scale $\mathrm{h}$ and determine how rapidly the variogram components change with increasing $h$.

4. Anisotropy of $A=1$, Angle $=0$. Although intensity may change more quickly in certain directions, the simplest scenario in which no preferred orientations exist, was chosen. The exact fault plane orientation of the studied earthquakes should be known in order to model the shape of the region in which intensities would vary faster.

5. Nugget effect $\mathrm{C}_{0}=1, \mathrm{EV}=0$, and $\mathrm{MV}=$ 1. These options cause a smoother interpolation. The nugget effect is the sum of the Error Variance (EV) and the Micro Variance (MV). EV is a measure of the repeatability of the data measurements. A non-zero EV implies that several observed values at one location are not necessarily the same value. Since only one value for each locality was used, the EV was set to zero. The MV is a measure of variation that occurs at separation distances of less than the typical nearest neighbor sample spacing. A value of one best fit the data, giving a smooth effect to the results.

The program draws isoseismals for any specified levels (or intervals) of MMI. Since MMI are represented only by integer values, isoseismals levels were selected following a convention that, for example, the region of intensity VI is bounded by the isoseismal lines of 5.5 and 6.5. This allows all the observed MMI values to be correctly separated by isoseismal lines in MMI regions.

\section{ISOSEISMAL MAPS OF THE SIGNIFICANT 2002-2003 EARTHQUAKES}

The kriging method has been tested using four Costa Rican earthquakes with different range of intensity values, density of observations, and epicentral locations. These seismic events are the January 28,
2002 Bijagua de Upala (5.4 Mw); the July 31, 2002 Burica (6.2 Mw); the September 16, 2003 Puriscal (5.4 Mw), and the 2003 Christmas (6.6 Mw) earthquakes. The Christmas earthquake was the best documented earthquake, with MMI values from 142 localities in Costa Rica, Panama and Nicaragua. The Burica, Bijagua, and Puriscal earthquakes were felt in a smaller area, and have MMI observations from 89,42 , and 40 localities, respectively.

\section{The January 28, 2002 Bijagua de Upala (5.4 Mw) Earthquake}

On Sunday, January 28, 2002, a shallow intermediate-magnitude earthquake (5.4 MW, depth $4.0 \mathrm{~km}$ ) occurred in northern Costa Rica. The epicentral location of the main event and its aftershocks suggest that these earthquakes occurred in the Caño Negro fault that runs along the northeast flank of the Miravalles and Tenorio volcanoes (Taylor et al., 2002; Fig. 2A, B).

Macroseismic information was collected between January 28 and 30, 2002, from 41 localities in Costa Rica and one in Nicaragua. The maximum MMI was VI at both Bijagua and El Pilón de Upala (black squares in Fig. 2B). The Kriging interpolation does not delimitate a MMI VI region because there were only two MMI VI locations that are geographically very close to each other $(\sim 5 \mathrm{~km})$. The earthquake was felt as far as Guácimo, $159 \mathrm{~km}$ away from the epicenter. There were not strong motion records of this earthquake because there are not LIS stations close to the epicenter and the event was not large enough to trigger the accelerographs located at larger distances. The closest station is located at Liberia, $48 \mathrm{~km}$ from the epicenter.

In the region of intensity VI, people reported difficulty standing. At El Pilón, three old wooden 


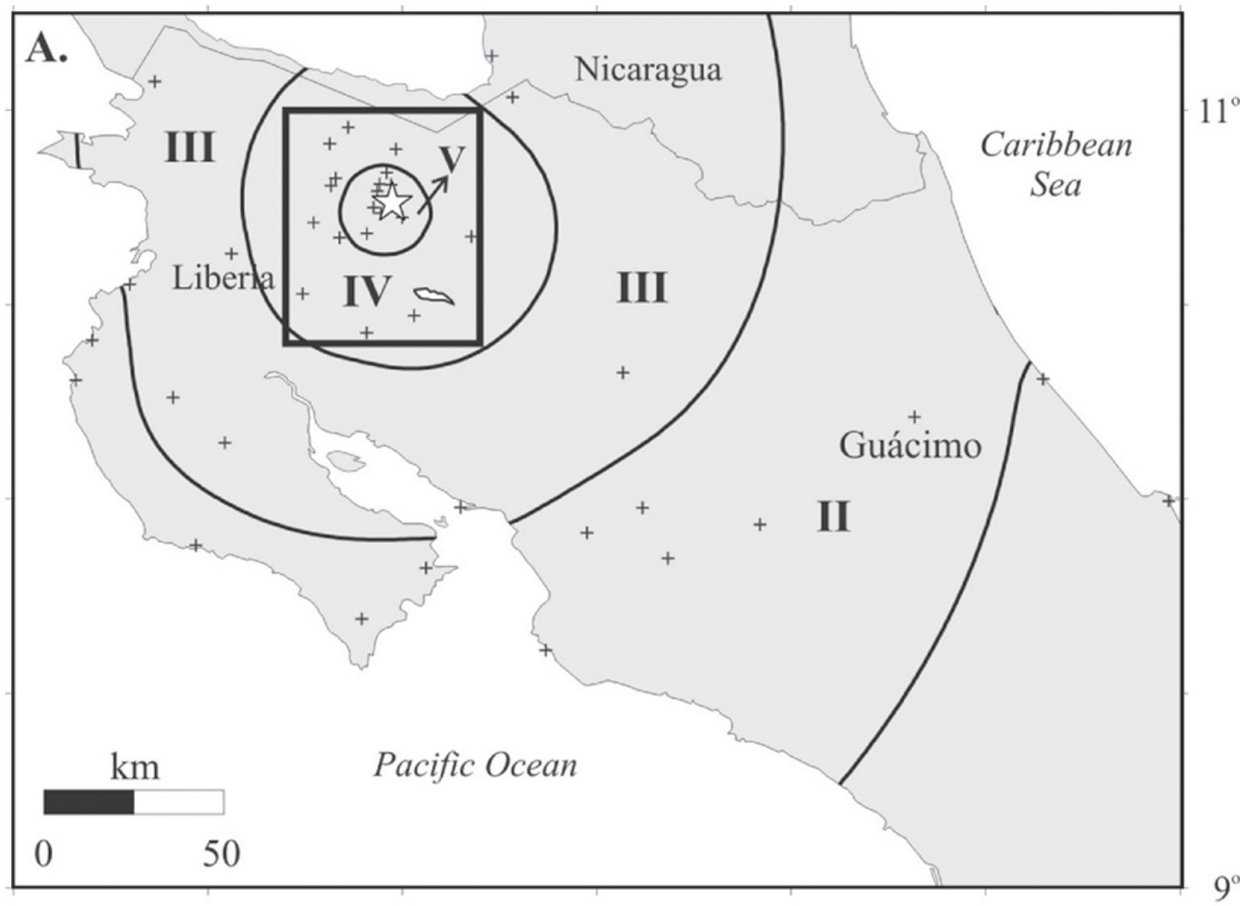

B.
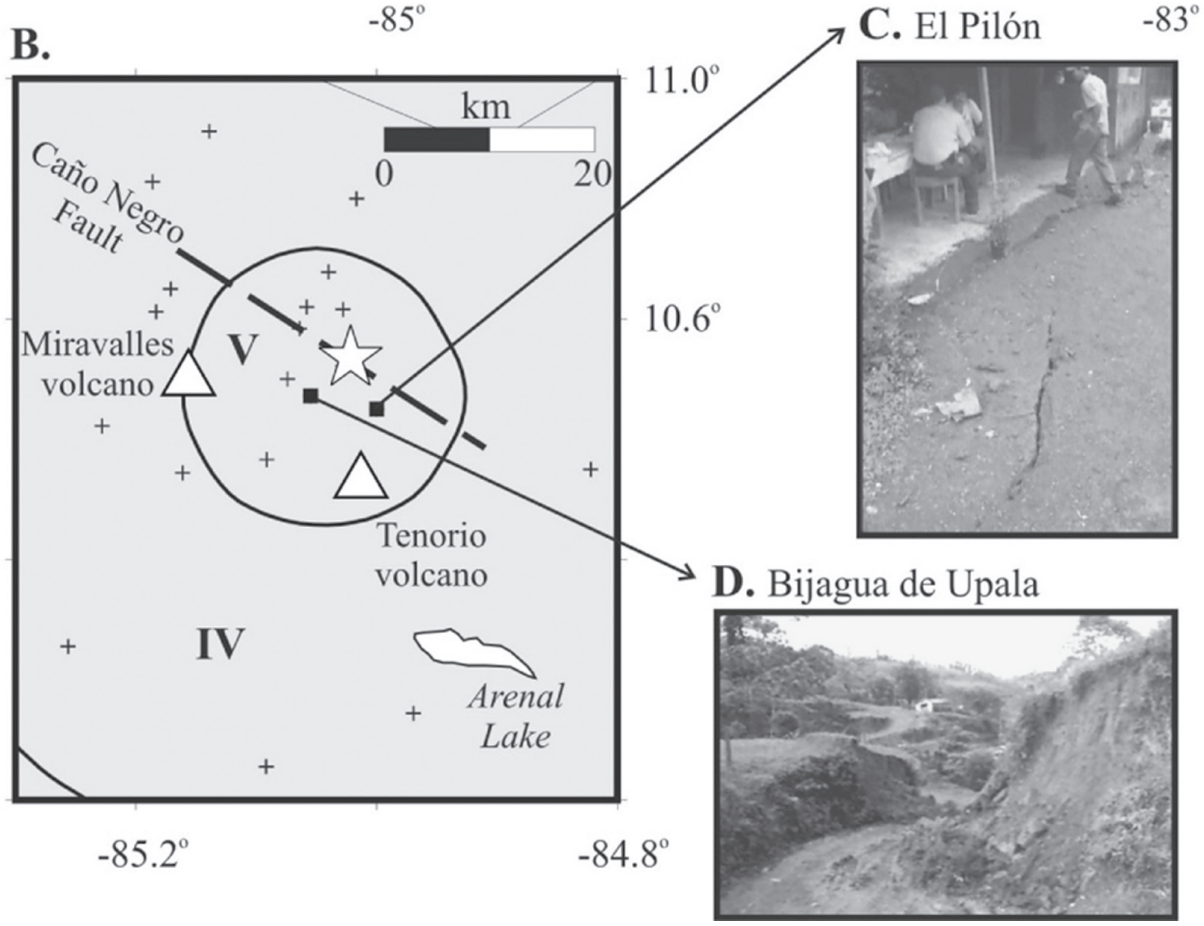

Fig. 2: A) Isoseismal map for the January 28, 2002 Bijagua de Upala (5.4 Mw) earthquake. The white star represents the epicenter and black crosses the location of observed MMI. B) Zoom of the MMI V region. Black squares denote the two localities where MMI VI was observed. Dashed line shows the approximate location of the Caño Negro fault based on its geomorphic expression. The Holocene volcanoes mentioned in the text are represented by white triangles. C) Ground cracks induced by fill compaction at El Pilón. D) Small landslides at Bijagua de Upala. 
houses were severely damaged because their bases were tilted. Small landslides, rock falls and 1-3 $\mathrm{cm}$ wide ground cracks were observed along segments of the road between Bijagua and El Pilón (Fig. 2C, 2D). At Bijagua, many people reported a rumble before the earthquake. Many or nearly all the objects fell off shelves and heavy furniture and appliances were displaced inside houses and local shops. Hairline cracks in walls were commonly observed. Water and electricity were suspended and restored after a couple of hours.

Two other important events occurred on January 27 (4.4 Mw) and January 30 (4.3 Mw). The large number of felt earthquakes during the first day of the seismic sequence produced the rumor among local people that a volcanic eruption would occur on the nearby volcanoes Miravalles and Tenorio. This forced people to leave their towns and take shelter in other cities for one or two days. There were no reports of injuries or fatalities due to these earthquakes.

\section{The July 31, 2002 Burica (6.2 Mw) Earthquake}

On July 31, 2002, a 6.2 Mw earthquake struck southern Costa Rica and western Panama. Two large aftershocks occurred on August 3 (5.9 $\mathrm{Mw})$ and August 8 (5.7 Mw). Earthquakes in the Burica peninsula region are usually associated with either right-lateral crustal faults located in the upper plate or with the Panama Fracture Zone (PFZ), which is a right-lateral strike-slip fault system defining the boundary between the Cocos and Nazca plates (Rojas et al., 2003; Fig. 1).

Interviews were conducted at 70 localities in Costa Rica, 18 in Panama, and one in Nicaragua, between July 31 and August 4, 2002. The maximum MMI was VII at small towns located along the Burica peninsula and in the city of Puerto Armuelles in Panama. The earthquake was felt as far as Canalete de Upala, $393 \mathrm{~km}$ from the epicenter (Fig. 3A, 3B). Five people were reported with minor injuries in Costa Rica and three in Panama. The earthquake destroyed 12 old wooden houses in small towns located along the political boundary between Costa Rica and Panama (Fig. 3C).
In the region of intensity VII, people reported difficulty standing or walking. Local shops sustained extensive economic loss because nearly all merchandise fell off from shelves. Heavy furniture and appliances fell over or were displaced inside houses and local shops. The collapse of free-standing masonry fences was also observed (Fig. 3D). At the city of Puerto Armuelles, the earthquake caused severe damage to the old pier, where the railing and light poles were tilted. Masonry fell from brick walls of the Banco del Istmo building. Hairline cracks in walls and broken windows were commonly observed at commercial shops and a few large cracks in concrete and brick walls were also noticed. Along the sand beach, 1-2 mm wide and 2-3 $\mathrm{m}$ long ground cracks were observed. The local hospital was evacuated after the earthquake. Minor damage in the form of hairline cracks was reported at David and Ciudad Neily hospitals.

The earthquake was recorded at nine LIS strong motion stations (Table 2, Fig. 1). The maximum PGA recorded was $32.6 \mathrm{~cm} / \mathrm{s}^{2}$ at station Golfito (GLF), located $77 \mathrm{~km}$ from the hypocenter. The second largest PGA was $26.3 \mathrm{~cm} / \mathrm{s}^{2}$ at station Alajuela (ALJ), the most distant station that recorded the earthquake. Station ALJ is located on a soft type soil, composed by weathered volcanic deposits. Local amplification effects might produce the higher acceleration values recorded at this station as compared to other stations that are closer to the epicenter.

\section{The September 16, 2003 Puriscal (5.4 Mw) Earthquake}

On September 16, 2003 an intermediate magnitude earthquake (5.4 Mw) occurred underneath the central part of Costa Rica. This earthquake was related to the subduction of the Cocos plate beneath the Panama microplate and had a focal depth of $55 \mathrm{~km}$ (Fig. 1).

Interviews were carried out at 40 localities in Costa Rica. The maximum MMI observed was V at San Ramón, Pavas and Guadalupe (Fig. 4). At these localities a few small objects were overturned and fell, a few knickknacks broke, small appliances were displaced, and pictures moved from walls. 

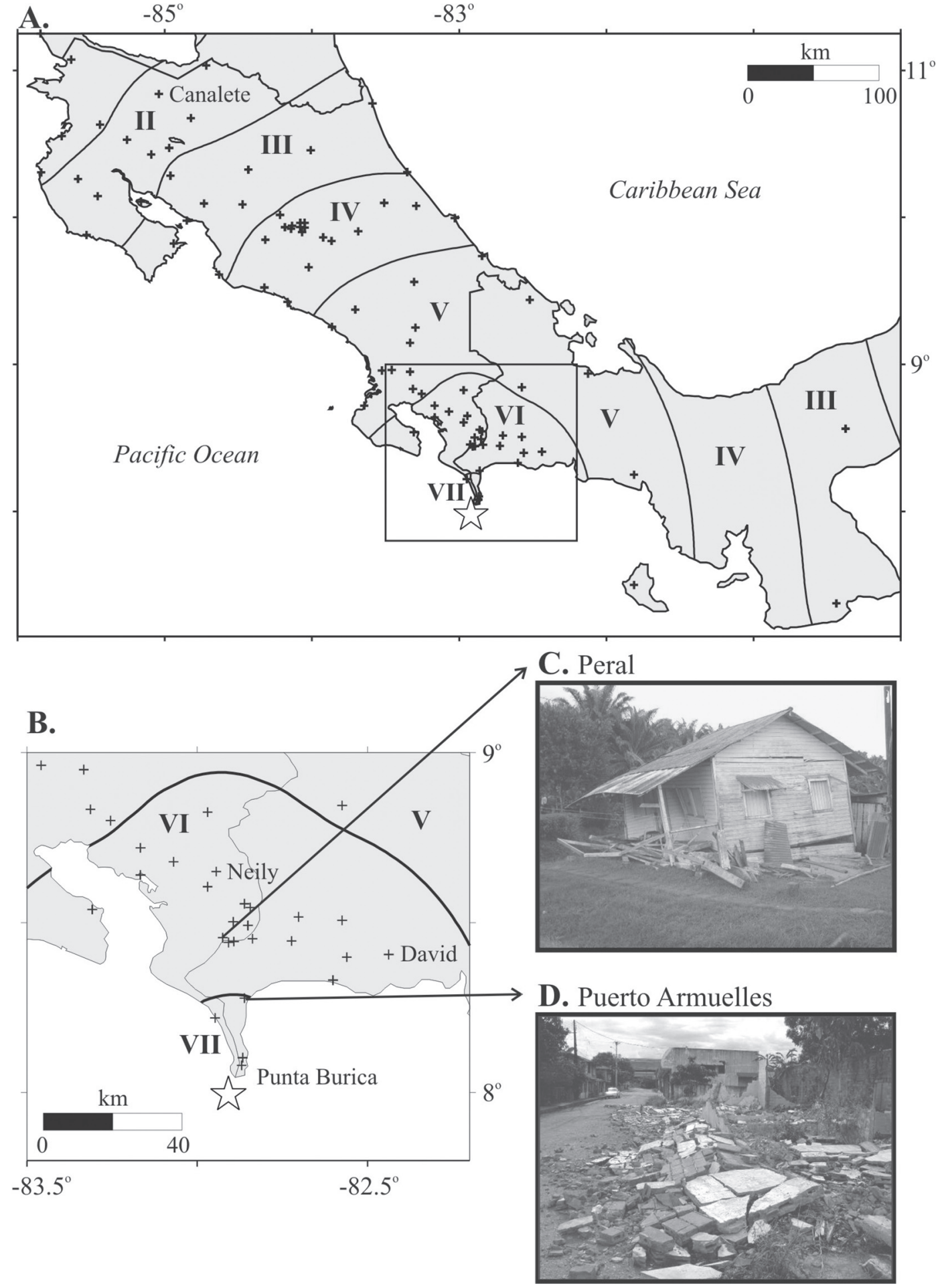

Fig. 3: A) Isoseismal map for the July 31, 2002 Burica (6.2 Mw) earthquake. The white star represents the epicenter and black crosses the locations of observed MMI. B) Zoom of the MMI VI and VII regions. D) Collapse of an old wooden house at Peral, Costa Rica. D) Collapse of free-standing masonry fences at Puerto Armuelles, Panama. 


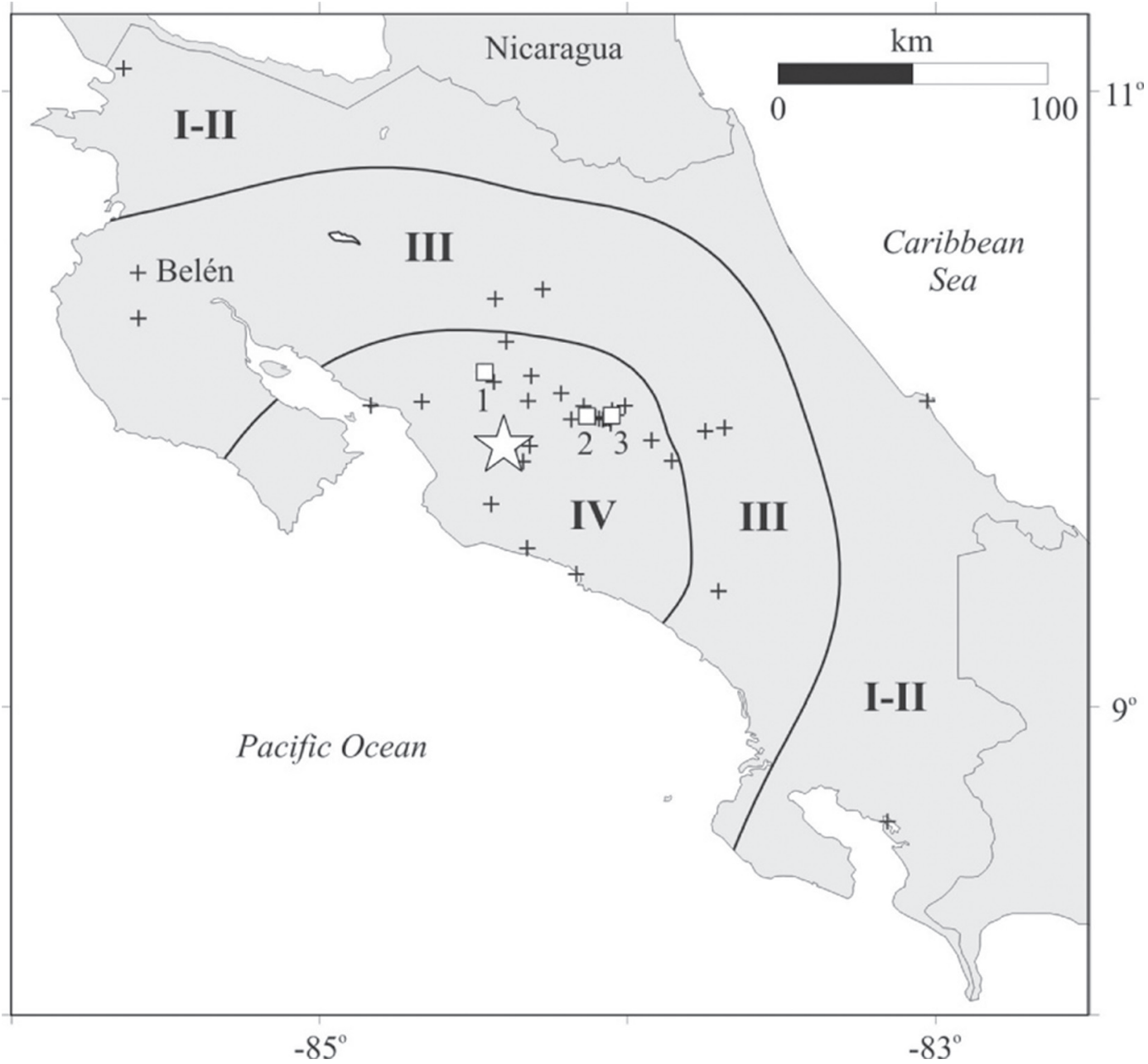

Fig. 4: Isoseismal map for the September 16, 2003 Puriscal (5.4 Mw) earthquake. The white star represents the epicenter and black crosses the locations of observed MMI. Numerated white squares denote the localities where MMI V was observed: 1 San Ramón, 2 Pavas, and 3 Guadalupe.

The earthquake was felt as far as Belén de Carrillo, $147 \mathrm{~km}$ from the epicenter. The event was recorded at 11 LIS strong motion stations (Table 2, Fig. 1). The largest PGA was $39.9 \mathrm{~cm} / \mathrm{s} 2$ at Escuela Católica Activa (ECA) in San José.

\section{The 2003 Christmas (6.6 Mw) Earthquake}

On Christmas day of 2003 at 1:11 a.m. local time, a strong earthquake struck Costa Rica and western Panama. Two large aftershocks occurred on January 7 (5.5 Mw) and February 4, 2004 $(5.8 \mathrm{Mw})$. The origin of these earthquakes may have been related to the Panama Fracture Zone (Barquero et al., 2004).

Interviews were made at 48 localities in Costa Rica and 10 in Panama between December 25 and 28, 2003. Additional macroseismic information from other 84 localities in Costa Rica, Panama and Nicaragua was obtained from RSN internal reports (Barquero et al., 2004; RSN, 2004). The earthquake was felt throughout Costa Rica and western Panama (Fig. 5). The maximum MMI was VIII observed only at Finca Naranjo (Fig. 5B). The earthquake was felt as far as San Juan del Sur, Nicaragua, $479 \mathrm{~km}$ from the epicenter. Two people were killed at Puerto Armuelles, 75 
A. $-83^{\circ}$
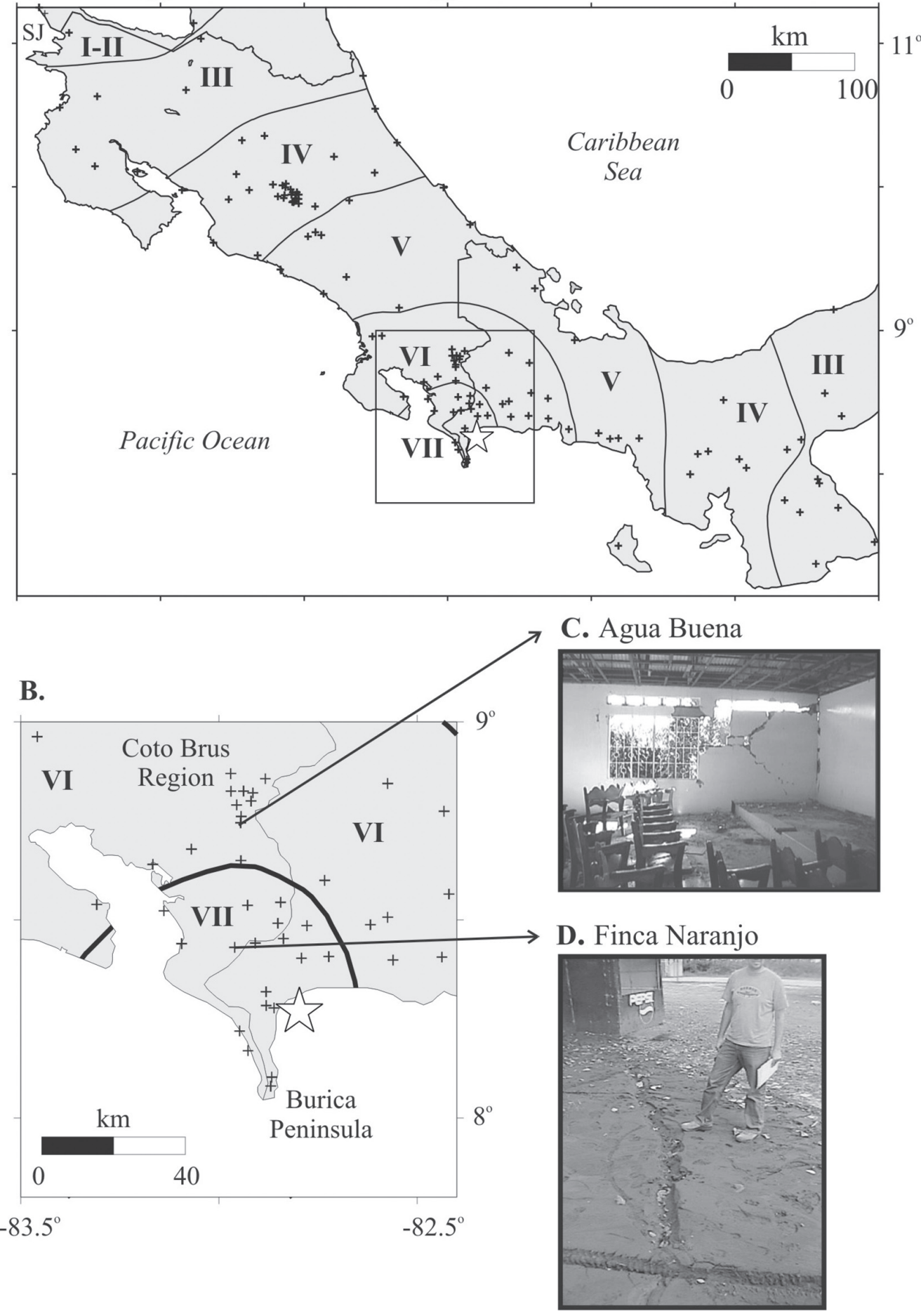

Fig. 5: A) Isoseismal map for the 2003 Christmas (6.6 Mw) earthquake. The white star represents the epicenter and black crosses the locations of observed MMI. SJ: San Juan del Sur de Nicaragua. B) Zoom to the MMI VII region. C) Damage on non reinforced brick walls of the Evangelic Church of Agua Buena de Coto Brus. D) Accumulation of sand due to liquefaction in Finca Naranjo. 
people were injured, 25 houses were totally destroyed, and at least 200 houses and public buildings presented minor or moderate damage.

Extensive liquefaction was observed at Finca Naranjo, which is located in young water-saturated, fine-grained alluvial deposits. Fill compaction occurred, producing cracks in the asphalt of local roads around Finca Naranjo. Ground crac$\mathrm{ks}$, as long as $5 \mathrm{~m}$ and as wide as $10 \mathrm{~cm}$, were commonly observed on roads, parks and inside houses. People reported that sand was ejected from ground cracks as high as $1.5 \mathrm{~m}$ from the surface. Piles of dark brown sand with an unpleasant odor were observed all over the region and inside houses, the park and the school (Fig. 5D). The local water pipe broke and the water supply was restored two days after the earthquake. Many large cracks were observed on the walls of houses, the school and other public buildings.

The region of intensity VII included the Burica Peninsula, the city of Puerto Armuelles in Panama, and small towns in the Coto Brus region. All people sleeping were awakened and reported difficulty standing or walking. A strong rumble before the earthquake was reported. People driving lost the control of their vehicles. Power outages of four to ten hours occurred in most of this region. The water system was damaged as well, and the water supply was reestablished after two days in some places. Small landslides were observed in the mountain region of Coto Brus and non-reinforced structures were severely damaged (Fig. 5C).

In the city of Puerto Armuelles, 12 non-reinforced brick houses collapsed, as well as many free-standing masonry fences. A few ground crac$\mathrm{ks}$ in the roads induced by fill compaction were observed. Railings and several light poles collapsed along the old pier, which was previously damaged by the 2002 Burica earthquake. Masonry fell from block or brick walls. A few large cracks occurred in masonry walls in new buildings, such as the Banco del Istmo and the Policentro. The outer walls of some commercial buildings were cracked, some windows were broken, and ceiling tiles fell down. Many ceiling tiles fell down at the fire station. Nearly all objects fell off from shelves, including televisions, and heavy furniture and appliances were displaced.
The earthquake was recorded at 17 LIS strong motion stations (Table 2). The maximum PGA obtained was $114 \mathrm{~cm} / \mathrm{s} 2$ at station Golfito (GLF), $63 \mathrm{~km}$ from the hypocenter. The station Alajuela (ALJ) recorded a peak value of $38.8 \mathrm{~cm} /$ $\mathrm{s} 2$, which is significant because the station is located $250 \mathrm{~km}$ away from the hypocenter. Higher PGA values at ALJ compared to stations located closer to the epicenter were also observed for the 2002 Burica earthquake, suggesting local amplifications effects for this site.

\section{LIMITATIONS OF THE METHOD AND FUTURE WORK}

One limitation of the interpolation method proposed in this paper is that the earthquake radiation pattern and the local geology are not yet considered. These two parameters may control the intensity observed at a particular location and could well be used as criteria to determine the isoseismal shape and trends that facilitate the line drawing in regions where MMI data is not available. The local geology could be added as an interpolation weight and the fault plane orientation using the anisotropy parameter. The incorporation of these two parameters in the interpolation algorithm has been left for future work in this subject.

A comparison of isoseismal maps using kriging and the traditional visual interpolation has also been left for future studies. Isoseismal maps made by visual interpolation using the same macroseismic data field for the studied earthquakes are not yet available. Since both methods are used as perfect interpolators, i.e., all MMI values are completely separated in MMI regions, little differences are expected to be noticed between maps made by Kriging and visual interpolation, when enough localities are used. The significance of the method presented here is that it offers a norm to create faster and homogeneous intensity maps.

Seismic intensity is a subjective parameter that may be biased by numerous factors such density of population, building practices, type of construction, and the social, economic and cultural environment. Both MMI data fields and the 
created intensity lines carry the subjectivity of the intensity parameter. This issue goes beyond the goals of this study, which gives interest on addressing the issue of drawing objective isoseismals lines based on intensity data fields.

\section{CONCLUSIONS}

The Kriging method is documented for the first time to draw isoseismal maps in Costa Rica. The technique was carried out using MMI values from four significant seismic events, each with varying intensity values, density of observations and epicentral locations. The earthquakes used were the January 28, 2002 Bijagua de Upala (5.4 $\mathrm{Mw})$; the July 31, 2002 Burica (6.2 Mw); the September 16, 2003 Puriscal (5.4 Mw), and the 2003 Christmas (6.6 Mw).

Kriging offers a method for drawing faster, objective, homogeneous and automatic isoseismal maps. For these reasons, kriging is recommended to replace the visual interpolation method that has traditionally been used in Costa Rica, although intensity maps made by visual interpolation are considered valid and accurate.

The kriging method predicts MMI values through consideration of the particular characteristics of the MMI data field, such as location of observed MMI values, inter-data spacing, and data repeatability at a particular location. Isoseismal lines were calculated by modeling the simplest variogram which accurately represent the observed intensity data field. The options used were Point and Ordinary Kriging, a linear variogram of slope $\mathrm{S}=1$, Anisotropy of $\mathrm{A}=1$ and Angle $=0$, and a nugget effect of $\mathrm{C} 0=1$.

The most notable effect observed for the studied earthquakes was the extensive liquefaction at Finca Naranjo for the 2003 Christmas earthquake, where the observed MMI was VIII. The Burica and Christmas earthquakes produced moderate damage at Puerto Armuelles and at small localities situated along the Panama-Costa Rican border region, where the MMI was VII. The Puriscal and Bijagua earthquakes produced only minor da- mage in the epicentral areas, where the Modified Mercalli Intensity (MMI) observed was V and VI, respectively.

PGA values recorded by the LIS were documented for these earthquakes. The maximum PGA recorded were: $39.9 \mathrm{~cm} / \mathrm{s}^{2}$ at ECA for the Puriscal earthquake, and $32.6 \mathrm{~cm} / \mathrm{s}^{2}$ and $114 \mathrm{~cm} /$ $\mathrm{s}^{2}$ at station GLF for the Burica and Christmas earthquakes, respectively. Local amplification effects were noted at ALJ stations, where higher acceleration values compared to stations closer to the epicenter were recorded for the Burica and Christmas earthquakes.

\section{ACKNOWLEDGEMENTS}

Partial funding for this study was provided by a ChevronTexaco Geology Fellowship and the John and Nancy Sumner Fellowship Awards from the Department of Geosciences of the University of Arizona. Thanks to Susan Beck, Walter Montero, Christine Gans, and an anonymous reviewer for their help improving the final manuscript. The following people collaborated during field trips to the epicentral areas: Wilfredo Rojas and Walter Montero (Bijagua earthquake), Ileana Boschini and Guillermo Alvarado (Burica earthquake), and Pablo Ruiz and Marco Barahona (Christmas earthquake). Thanks to the LIS personnel, particularly to Víctor Schmidt and Carlos Segura, for making the PGA data available.

\section{REFERENCES}

ALBARELLO, D., BERARDI, A., MARGOTTINI, C. \& MUCCIARELLI, M., 1995: Macroseismic estimates of magnitude in Italy. - Pure Appli. Geophys. 145: 297-312.

BARQUERO, R. \& ROJAS, W., 1994: Catálogo de mapas de isosistas de temblores y terremotos importantes de Costa Rica. - No págs. RSN [Internal report]. 
BARQUERO, R., LINKIMER, L., ROJAS, W., BOSCHINI, I., TAYLOR, W., ALVARADO, G., FERNÁNDEZ, M. \& MORA, M., 2004: El terremoto de Navidad del 25 de diciembre del 2003. - 33 págs. RSN [Internal report].

BOSCHINI,I.\& MONTERO, W., 1994: Sismicidad histórica e instrumental del Caribe de Costa Rica. - Rev. Geol. Amér. Central, vol. esp. Terremoto de Limón: 65-72.

CECIĆ, I., MUSSON, R., M.W. \& STUCCHI, M., 1996: Do seismologists agree upon epicenter determination from macroseismic data? A survey of ESC working group "macroseismology”. - Annali di Geofisica, 39: 1013-1027.

COLEGIO FEDERADO DE INGENIEROS Y ARQUITECTOS, 2003: Código sísmico de Costa Rica 2002. - 288 págs. Ed. Tecnológica de Costa Rica, Cartago.

CRESSIE, N., 1990: The origins of kriging. Math. Geol. 22: 239-252.

CRESSIE, N., 1991: Statistics for spatial data. - 900 págs. Wiley, New York.

DAVIDSON,C., 1921: On scales of seismic intensity and on the construction and use of isoseismal lines. - Bull. Seismol. Soc. Amer. 9: 95-129.

DAVIS, J., 1973: Statistics and data analysis. - 550 págs. Wiley, New York.

DE RUBEIS, V., GASPARINI, C., MARAMAI, A, MURRU, M. \& TERTULLIANI, A., 1992: The uncertainty and ambiguity of isoseismal maps. - Earthquake Engineering and Structural Dynamics, 21: 509-523.

DE RUBEIS, V., TOSI, P., GASPARINI, C. \& SOLIPACA, A., 2005: Application of the kriging technique to seismic intensity data. - Bull. Seismol. Soc. Amer. 95: 540-548.
FRANKEL, A., 1994: Implications of felt areamagnitude relations for earthquake scaling and the average frequency of perceptible ground motion. - Bull. Seismol. Soc. Amer. 84: 462-465.

GASPARINI, C., TOSI, P. \& DE RUBEIS, V., 2003: Northern Sicily, September 6, 2002 earthquake: investigation on peculiar macroseismic effects. - Annals Geophys. 46: 1361-1366.

GASPERINI, P., BERNARDINI, F., VALENSISE, G. \& BOSCHI, E., 1999: Defining seismogenic sources from historical earthquake felt reports. - Bull. Seismol. Soc. Amer. 89: 94-110.

GUPTA, H. \& COMBS, J., 1978: Investigation of isoseismals for some large magnitude earthquake in China. - Bull. Seismol. Soc. Amer. 68: 108-204.

ISAAKS, E. \& SRIVASTAVA, R.M., 1989: Applied geostatistics. - 561 págs. Oxford, New York.

KRIGE, D., 1951: A statistical approach to some basic mine valuation problems on the Witwatersrand. - J. Chem. Metallurg. Mining Soc. South Africa, 6: 119-139.

LINKIMER, L., 2007: Relationship between peak ground acceleration and Modified Mercalli intensity in Costa Rica. - Rev. Geol. Amér. Central, 36: xx-xx.

MATHERON, G., 1963. Principles of Geostatistics. - Econ. Geol.. 58: 12461266.

MONTERO, W., 1999: El terremoto del 4 de marzo de 1924 (Ms 7,0): Un gran temblor interplaca relacionado al límite incipiente entre la placa Caribe y la microplaca de Panamá? - Rev. Geol. Amér. Central, 22: 21-58. 
MONTERO, W. \& MIYAMURA, S., 1981: Distribución de intensidades y estimación de los parámetros focales de los terremotos de Cartago de 1910, Costa Rica, América Central. - Inf. Sem. IGN, 1981(2): 9-34.

MORA, S. \& YASUDA, S., 1994: Licuefacción y fenómenos asociados durante el terremoto de Limón. - Rev. Geol. Amér. Central, vol. esp. Terremoto de Limón: 121-132.

NUTTLI, O.W. \& ZOLLWEG, J.E., 1974: The relation between felt area and magnitude for central United States earthquakes. - Bull. Seismol. Soc. Amer. 64: 73-85.

PAPAZACHOS, C., 1992: Anisotropic radiation modeling of macroseismic intensities for estimation of the attenuation structure of the upper crust in Greece. - Pure Appl. Geophys. 138: 445-469.

PERALDO, G. \& MONTERO, W., 1994: Los temblores del período colonial de Costa Rica. - 162 págs. Ed. Tecnológica de Costa Rica, Cartago.

PERALDO, G., \& MONTERO, W., 1999: Sismología histórica de América Central. 347 págs. Inst. Panam. Geogr. Hist. México.

RICHTER, C.F., 1958: Elementary seismology. - 168 págs. Freeman, San Francisco.

ROJAS, W.\& REDONDO, R., 2002: El temblor de Quepos del 20 de agosto de 1999 (6,9 Mw): fuente sísmica y evolución de la sismicidad. - Rev. Geol. Amér. Central, 26: 65-70.

ROJAS, W., BUNGUM, H. \& LINDHOLM, C., 1993: Historical and recent earthquake in Central America. - Rev. Geol. Amér. Central, 16: 5-22.

ROJAS, W., LINKIMER, L., MONTERO, W., FLORES, H., REDONDO, C. \& BOSCHINI, I., 2003: Actividad sísmica de la región de la península Burica asociada con la ruptura del 30 de julio del 2002 (Mw 6,2), costa pacífica de Panamá y Costa Rica. - 31 págs. RSN [Internal report].

RSN, 2004: La actividad sísmica en la región sur de Costa Rica de diciembre del 2003 a febrero del 2004. - 35 págs. RSN [Internal report].

SCHENKOVÁ,Z., SCHENK, V.,KALOGERAS, I., PICHL, R., KOTTNAUER, P., PAPATSIMBA, C. \& PANOPOULOU, G., 2007: Isoseismal maps drawing by the kriging method. - J. Seismol. 11: 121-129.

SHEBALIN, N.V., 1973: Macroseismic data as information on source parameters of large earthquake. - Phys. Earth Planet. Int. 6: 316-323.

SUÁREZ, G., PARDO, M., DOMÍNGUEZ, J., PONCE,L., MONTERO, W., BOSCHINI, I. \& ROJAS, W., 1995: The Limón, Costa Rica earthquake of April 22, 1991: Back arc thrusting and collisional tectonics in a subduction environment. - Tectonics, 14: 518-530.

TAYLOR, W., BARQUERO, R., ROJAS, W., MONTERO, W. \& LINKIMER, L., 2002: Crisis sísmica de Bijagua de Upala (EneroMarzo del 2002), Costa Rica. - Bol. OSIVAM, 13(25): 48-66.

WALD, D.J., QUINTORIANO, V., HEATON, T.H., KANAMORI., H., SCRIVNER, C.W. \& WORDEN, C.B., 1999: TriNet "ShakeMaps": Rapid generation of peak ground motion and intensity maps for earthquakes in southern California. Earthquake Spectra, 15: 537-555.

WHITE, R. \& HARLOW, D., 1998: Destructive upper-crustal earthquakes of Central America since 1900. - Bull. Seismol. Soc. Amer. 88: 1115-1142.

WOOD, H.O. \& NEWMAN, F., 1931: Modified Mercalli intensity of 1931. - Bull. Seismol. Soc. Amer. 21: 277-283. 